\title{
5 \\ QUANTIFYING MISSING AND HIDDEN TRADE
}

\section{An economic perspective}

\author{
Sami Bensassi and Jade Siu
}

\section{Introduction}

Quantifying smuggling is necessary for researchers and policy makers to understand its connection with the political, economic, and social system. It is also a necessary step to answer policy questions, such as those related to public finances, trade and industrial development. Despite its necessity, measuring smuggling activities is inherently difficult. Researchers are continuously confronted with the challenge of assessing the extent to which the data they have on the characteristics, activities, and behaviours of smugglers are accurate and complete. To what extent can we trust what respondents report? What type of smuggling activities are we able to capture and what type of activities are we not able to capture? How are the data which we collect affected by those who collect them?

Another challenge in quantifying smuggling arises from the fact that the (il)legality of trading activities is not a binary concept. The degree to which traders are compliant with the law varies, and could be visualised as a spectrum. On one end of the spectrum, there exist traders who are complying fully, paying all necessary taxes, abiding by regulations, and registering officially. Trading activities away from that end of the spectrum could be labelled as smuggling. Due to the heterogeneous nature of smuggling, quantifying smuggling becomes complex and perhaps seemingly impossible. In this chapter, we provide a starting point to break down this complexity. We categorise two types of smuggling activities: "missing" trade and "hidden" trade. We define "missing" trade as the trade of goods which are declared correctly in the custom office of one country but not in the office of another country. For example, some goods might be misclassified as another product or under-invoiced so as to reduce the amount of tax which needs to be paid. Scholars have been taking advantage of this characteristic to detect smuggling activities by uncovering discrepancies, or "missing" trade, existing between flows recorded by the custom offices of the exporting and importing countries for the same bilateral exchange. These methodologies have evolved from using aggregated country-level trade flow datasets, which are usually publicly available, to using highly disaggregated custom-level data.

There are trade flows which do not pass through customs at all. Accordingly, unlike "missing trade," these trade flows are "hidden" and cannot be detected by examining statistical discrepancies in customs records (see Figure 5.1). Nevertheless, they are prevalent in land borders, and there has been an increasing recognition amongst governments and scholars that 


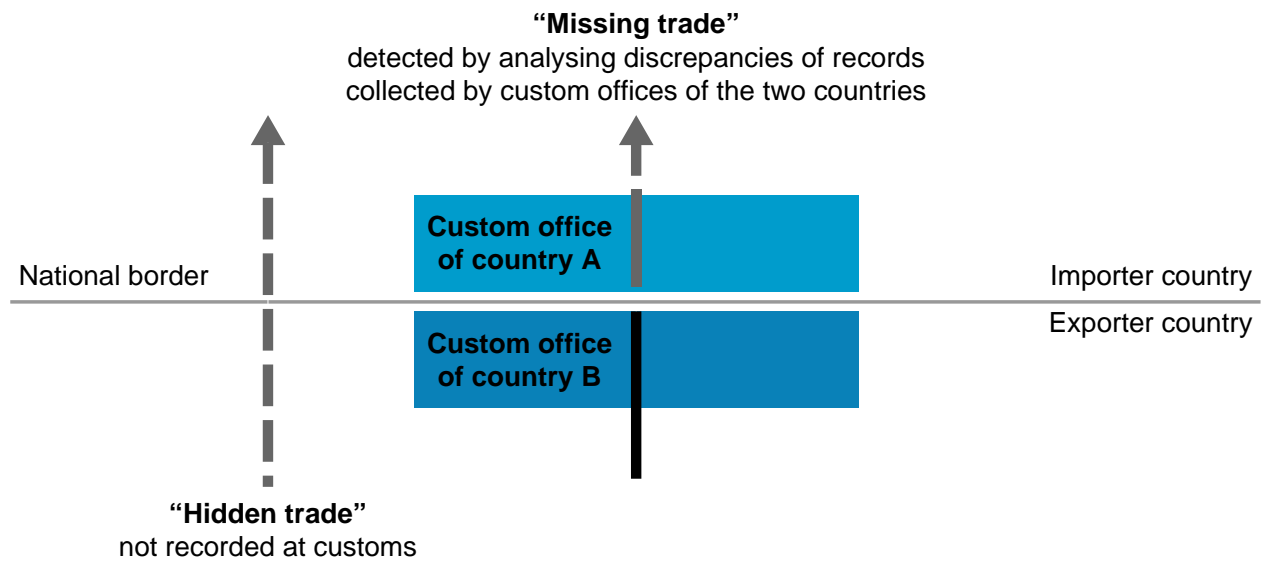

Figure 5.1 Difference between "missing trade" and "hidden trade".

ignoring "hidden trade" would lead to an underestimation of the size of smuggling. In this chapter, we review the relevant methodologies used to quantify "missing" and "hidden" trade.

While estimating the size of smuggling is a useful starting point to gauge its importance in an economy and to explore factors associated with smuggling at a macro level, more information is needed to delve into the nuance behind the motivations and behaviours of various actors involved in smuggling. Why do smugglers smuggle, and how? What are the incentives of other actors, such as customs officers? What would change their behaviours? Even if incentives could be designed to adjust their behaviour, would this be socially and economically desirable? In the past few years, economists have begun to explore these questions quantitatively using microdata on individuals and firms who engage in smuggling in some way.

While these studies have provided new insights by quantifying the extent of associations, causes and consequences of smuggling at a micro-level, the literature remains thin, and richer analysis using mixed methods is needed.

We begin the Chapter by reviewing the earlier attempts to test economic theories on smuggling. We then examine the developments of various tools to detect "missing trade" after the seminal work by Bhagwati (1964) in Section 3. In Section 4, we review the progress made to capture the size of "hidden trade." In Section 5, we discuss recent quantitative studies using micro-data. We conclude in Section 6 by discussing the future research agenda to better quantify the size of smuggling, and its impact on different aspects of our lives. This Chapter focuses on the smuggling of goods which are legal themselves, as opposite to goods, such as narcotics, wildlife products and arms, which are illicit. The trade activities which we describe are also known as informal cross-border trade (ICBT), and can occur in both land borders and at ports. Our examples are mainly drawn from East and West Africa, the area of our expertise, but these methods are applicable to other regions with porous borders. Due to our background, we put greater focus on discussing the economics literature but we also draw on quantitative studies beyond the field of economics when appropriate.

\section{From theory to data}

During the 1960s and 1970s, trade economists were keen to understand whether smuggling enhances or reduces welfare. The pioneering work by Bhagwati and Hansen (1973) provides a 
model to understand the welfare effect of smuggling by incorporating smuggling into trade theory involving two goods which can be traded with transportation costs. This framework examines whether the presence of smuggling enhances welfare through increasing overall levels of trade, or reduces welfare, through diverging trade. ${ }^{1}$ They found that if tariffs are not prohibitive, smuggling is generally welfare-reducing.

Theoretical models of smuggling have evolved since Bhagwati and Hansen (1973) to incorporate more realistic smuggling behaviour and market structures which provide a better understanding of the mechanisms through which smuggling can affect welfare. For example, theories have sought to refine the modelling of costs and risks faced by smugglers, such as cost of goods being confiscated and fined (Sheikh 1974), costs of packaging to hide smuggled goods (Thursby et al. 1991), as well as the stringency of enforcement (Martin \& Panagariya 1984). Even so, models fail to take into account that smuggling is most perverse in economies where weak institutions and poor infrastructure have pushed up trade costs. With that in mind, by extending Bhagwati and Hansen's (1973) model, Deardorff and Stolper (1990) found that smuggling is in general, welfare-enhancing. They argue that in African economies where there are large market inefficiencies, traders conduct informal trade for survival, rather than purely to evade tax. The inefficiencies which they refer to are trade regulations imposed by governments, such as quotas and price controls. Instead of modelling smuggling requiring an extra resource cost, they model smuggling as a cheaper option than formal trade when regulations are too cumbersome and costly. More recently, using a modern bilateral trade model, Dutt and Traca (2010) theoretically modelled tariff evasion and corruption, and found that the welfare effect of corruption associated with tariff evasion is ambiguous, and is dependent on the level of tariffs.

Despite working with limited reliable data at the time, scholars made innovative use of key macroeconomic data, such as prices and exchange rates, to test these theories. For example, Pitt (1981) directly tests Bhagwati and Hansen (1973)'s theory by defining the incentive to smuggle as the black market exchange rate divided by official effective exchange rate for rubber export in Indonesia. He argues that Bhagwati and Hansen (1973)'s model is inconsistent with his data. Against the backdrop of the implementation of structural adjustment programs, which includes devaluation, Dercon and Ayalew (1995) compares incentives for smuggling coffee, which is affected by the parallel market exchange rate, before and after the revolution in Ethiopia (from 1974).

Estimating the extent of smuggling has also become more sophisticated as more up-to-date and disaggregated data on prices and production of goods become available. Golub and Mbaye (2009) demonstrate the usage of several key economic indicators to estimate the size of smuggling between The Gambia, a country with a relatively free trade regime, and Senegal which takes a more protectionist approach to its trade policies. While it is widely known that there are large volumes of re-exports from The Gambia to Senegal, the official trade statistics collected by the Senegalese customs show that there is almost none. Golub \& Mbaye (2009) firstly quantify the amount smuggled from The Gambia to Senegal by making use of the fact that, in absence of smuggling and measurement errors, domestic consumption is equal to domestic production plus net imports (imports minus exports). They construct a simple ratio of net imports minus production over domestic consumption for Gambia. If all trade is recorded, this ratio should be $100 \%$. A ratio larger than $100 \%$ suggests that there exists some trade activities not recorded by the customs. They found that in 2004 , this ratio for sugar was $400 \%$, indicating a large volume of sugar imported into Senegal is unrecorded. They also used a second method to understand the incentives behind smuggling. They compared the wholesale prices of relatively homogenous goods, such as sugar, rice and wheat, in Banjul, The Gambia and Dakar, Senegal. They found that there were substantial price differences between the two places, and 
this was especially pronounced in the case of sugar, in line with the first evidence. Similarly, sugar was found to have especially large differences in trade taxes between the two countries. This study provides a good example of how to make effective use of different data sources and methods to triangulate the size of smuggling.

\section{Quantifying “missing” trade}

One of the most widely adopted methods of detecting smuggling today is the one originally proposed by Bhagwati (1964). This method focuses on estimating a specific type of smuggling. This type of smuggling, or "quasi-smuggling" as labelled by Bhagwati and Hansen (1973), involves goods that are transported through customs offices, but under-invoiced to reduce the amount of tax which needs to be paid. For example, a trader evades taxes by misreporting the price of the product or the quantity of the product. The method of quantifying this "missing" trade involves comparing the data provided by national customs agencies of the exporting and importing countries for the same trade flow in a given time. In particular, trade statistics provided by the exporting country tend to be more accurate than trade statistics provided by the importing country, since traders have the incentive to evade import duties. The method, known as mirror statistics or trade gaps, has the advantage of simplicity. It involves a computation of straightforward subtractions, and makes use of publicly available data, such the UN COMTRADE database, which is the principal source of trade data.

Bhagwati (1964) was also clear about the limitations inherent to this method. It is not possible to rule out other reasons such as time differences in reporting, errors in reporting, or the use of third country in international trade (entrepots economies) to explain the observed discrepancies. He states “"proof [of smuggling] is thus impossible; only 'plausibility' can be procured by the method proposed" (Bhagwati, 1967, p. 70).

For three decades, Bhagwati's (1964) mirror statistics method attracted very few interests. It was not until the seminal paper of Fisman and Wei (2004) when Bhagwati's (1964) method was applied into econometric analysis. Using disaggregated trade data between Hong Kong and mainland China, Fisman and Wei (2004) found that there is a strong positive relationship between the extent of trade gap and tariff rates: one percent point increase in tariff rates is associated with 3\% increase in trade gap. (5.1) shows the formulation of the trade gap which they adopted, and have since been extensively used in other studies. The subscripts $\mathrm{i} ; \mathrm{j} ; \mathrm{k}$ and $\mathrm{t}$ indicate that the gap value is calculated for the trade flowing from country $i$ to country $j$, for a category of product $\mathrm{k}$ at a specific time $\mathrm{t}^{2}$

$$
\text { gapvalue }_{\mathrm{ijkt}}=\log \left(\text { exportvalue }_{\mathrm{ijkt}}\right)-\log \left(\text { importvalue }_{\mathrm{ijkt}}\right)
$$

Fisman and Wei (2004) also extended Bhagwati (1964)'s method to not only detect tax evasion by firms underreporting the value of imported goods but also to detect tax evasion achieved by firms purposefully misclassifying products. By intentionally mis-reporting the classification of the product, traders are then subject to lower taxes compared the taxes if they were to declare the importation of the actual good. Fisman and Wei (2004) investigates the extent of tax evasion through misclassification by calculating the average tax rate of a group of products which are "similar," defined as being in the same four-digit category of the Harmonized System code. They found that, keeping tax rates as constant, trading a good in a group of "similar" products with a lower average tariff increases the trade gap. 
Javorcik and Narciso (2008) extend this method by examining the extent to which tariff evasion is more prevalent for products which are more "differentiated" (e.g., shoes) than products which are homogenous (e.g., Irish potatoes), as it is harder for the customs officer to assess the true price of a "differentiated" product. In addition, they distinguish the channels through which tariff evasion is implemented: is it by misreporting quantity or is it by misreporting price? They do this by first examining the differences in quantity recorded by exporting and importing countries (which should be close to zero if there exists no quantity misreporting), and then separately examine the differences in unit values recorded by the exporting and importing countries (importing country should have higher unit value than exporting value as it includes cost of freight and insurance). They found evidence that tariff evasion between Germany and Eastern European countries are through the channel of misreporting price rather than through misreporting quantities.

Several studies followed, quantifying the associations between trade gaps and tariffs measures for various countries and products. Mishra et al. (2008) found that higher trade gaps between India and its top 40 trading partners are associated with higher tariffs, with an association stronger for differentiated products. Similar results are found for Kenya, Mauritius and Nigeria (Bouet \& Roy 2012), trade between Kenya and Tanzania (Levin \& Widell 2014) and for Ethiopia (Mengistu et al. 2018).

The method of trade gap is then applied to understanding beyond the association of tariff evasion and tariff measures. These include studies which examine the relationship between trade gap and corruption (Berger \& Nitsch 2008, Jean \& Mitaritonna 2010, Worku et al. 2016, Kellenberg \& Levinson 2019), political connections (Rijkers et al. 2017), trade agreements (Stoyanov 2012, Sequeira 2016, Javorcik \& Narciso 2017), export restrictions (Vézina 2015) and VAT (Ferrantino et al. 2012). These studies show that the trade gaps can be large and are observed in various settings (between developing nations, between developed countries, and between developing and developed countries). They have provided consistent evidence that these gaps are connected to the level of tariffs in the importing country and corruption in the importing and exporting countries.

Another method which makes use of customs data is the price filter method. First proposed by Paul et al. (1994), this method has been used in a number of studies (de Boyrie et al. 2005a, de Boyrie et al. 2005b, 2007). One of the benefits of the price filter method is that it is practical. It makes use of data that customs agencies gather on a day-to-day basis. The method detects fraud by comparing the reported price of a particular shipment with what could be considered the arm's length price, or an objective price, of the goods traded. If the reported price is abnormal - above or below the arm's length price range - the record of the shipment is considered suspicious. This arm's length price can be calculated in different ways. For example, if a market price is available, the market price plus or minus a certain percentage can be used as the arm's length price. In occasions when market prices are not available, one can use the average price of shipments of similar goods (WCO 2018). This corpus of research also has been valuable in showcasing and perfecting this method to help customs agencies flag potential unlawful behaviours.

Nonetheless, the arm's length price thresholds used to compare prices could be ad-hoc. Customs officers may not be well-informed about the actual value of the goods and thus unable to determine whether the value declared by the importer is accurate or not. By using a randomized control trial (RCT), Chalendard et al. (2020) found that providing more detailed and precise valuation information to customs officers at the ports of Mozambique can increase fraud detection. There are also other countries which seek to provide additional information to customs officers through pre-shipment inspection of imports (PSI), where a private firm 
provides a report to the importing customs, verifying the classification and valuation of the goods before shipment. While this could reduce tax avoidance of the goods which require such a report to be issued, total tax avoidance may not have decreased if there are alternative methods to smuggle, as found in Yang (2008) in the ports of the Philippines.

Recently, Demir and Javorcik (2020) proposed a new method which makes use of a statistical test to detect import tax evasion. More specifically, they make use of the Benford's law, which provides the probability a number will appear as a leading digit $^{3}$ in a dataset. They found that while export statistics and import statistics of goods which are not subject to tariffs conform with the law, import statistics of goods which are subject to taxes do not. This provides an indication that deviation from the law is related to import tax evasion.

They then measured the extent of import tax evasion by calculating the deviation from the law. They also found that their results, when using this new method of detecting import tax avoidance, are consistent with using the trade gap method proposed in Fisman and Wei (2004).

Despite the extensive usage of these indirect methods, the "original sin" of these methods comes back to haunt economists interested in smuggling and tax avoidance as soon as it is used in institutional and political debates connected to these questions. A telling example has been the controversy followed by the publication of the 2016 UNCTAD report on illicit financial flows. Denouncing the behaviour of specific countries based on the trade gap method opened a stream of justified criticisms vis-a-vis the origin of the gaps and risked a rebuke of any analysis based on this methodology. As cautioned by Bhagwati (1964), there could be various reasons other than smuggling activities, which explain the presence of discrepancies in trade statistics. Forstater (2018) highlights some of these factors, which include discrepancies between trade statistics provided by UN COMTRADE and those provided by national statistical offices. The use of mirror statistics also relies on one reporting country having an accurate set of trade statistics, which could be the case for trade flows involving a high-income country. This could be problematic when attempting to detect smuggling between two low-income countries which may have low statistical capacity. In addition, while trade statistics aggregated at a high level are easily accessible to all researchers, mirror statistics are most revealing when using highly disaggregated trade data.

If these indirect methods are able to provide only a partial picture of smuggling occurring at customs, it does not provide any information about trade flows which are not recorded either side of the border. Such trade flows are prevalent among low-income countries. This issue of "hidden trade" has been known through qualitative and case studies for a long time (Igue \& Soule 1992, Titeca \& Celestin 2012, Walther 2015, Bensassi et al. 2017). The next section of this chapter is dedicated to discussing methods used to reveal this trade.

\section{Quantifying the "hidden" trade}

Much of the "hidden" trade, although not recorded in national statistics, is highly visible in real-life. While some traders intentionally avoid customs offices to evade taxes, other traders are crossing borders which were part of historic trading routes before the borders were drawn (Golub 2015). In recent years, there has been a shift in perspectives, by some governments and international organisations, from criminalising these activities to acknowledging that some of this informal trade could play a role in reducing poverty and food insecurity (Afrika \& Ajumbo 2012, Koroma et al. 2017).

As part of this shift, there has been increasing effort by governments to collect data on these informal trade activities. In the perspective of a government, understanding the level of informal trade is not only for the purposes of law enforcement and tax revenue collection, but also 
for basic accounting purposes. For countries with porous borders, relying on official trade statistics will skew the actual trade balance. For example, Uganda has found that their trade balance figures from Bank of Uganda (BoU) were USD 500 million higher than those recorded by the Ugandan Bureau of Statistics (UBOS) on the expenditure side of the National Accounts. They later were able to reconcile the gap, explained partly by informal cross-border trade (UBOS 2006).

Data collection efforts by governments are varied. In the case of sub-Saharan Africa, to our knowledge, Uganda has implemented the longest-standing systematic survey on informal cross-border trade. The pilot took place in 2004, and the full survey has been implemented every month since then. Its neighbouring country, Kenya, has also implemented a similar data collection exercise, but only for one month in 2011 and 2012 (KNBS 2012). We show the border crossings which have been monitored through these efforts in Uganda and in Kenya in Panel A of Figure 5.2. Rwanda also has been monitoring informal trade at all its border crossings since 2012 (NISR 2014). In West Africa, Nigeria has conducted a similar survey in 2013 and 2014 (CBN 2016), and Benin in 2010 and 2011 (INSAE 2011). Although the data collection in Benin was only implemented for one month in 2010 and 2011, the survey covered

(a) Panel

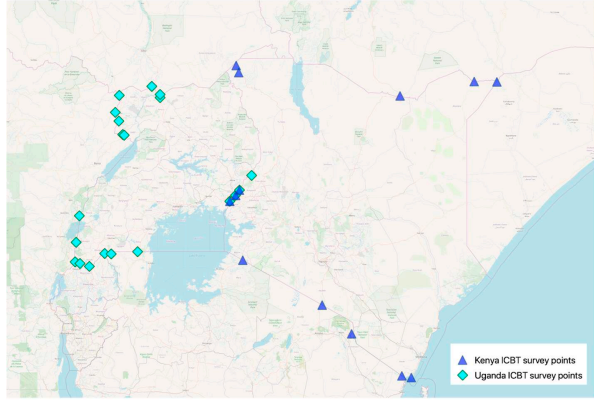

(c) Panel

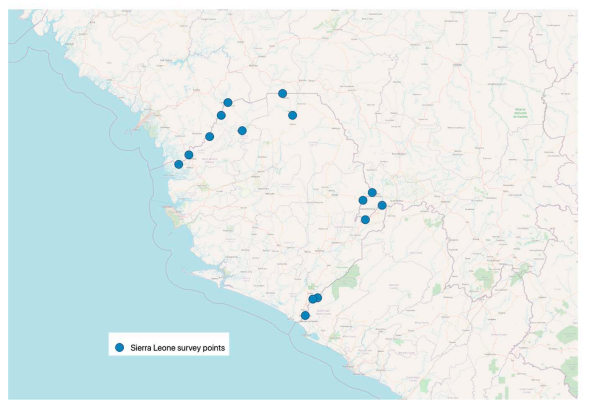

(b) Panel

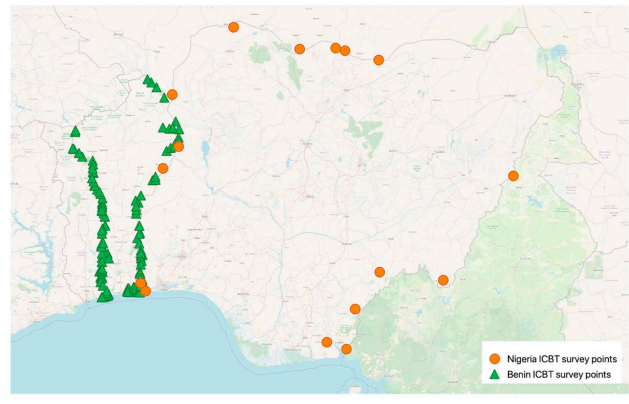

(d) Panel

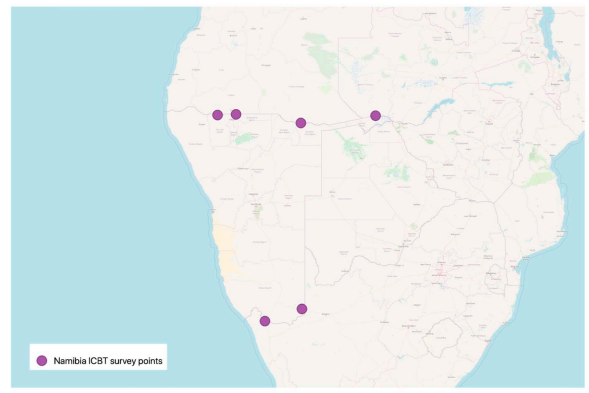

Figure 5.2 ICBT survey points monitored by governments of Nigeria and Benin.

Notes: Panel A are the border crossing points monitored by the governments of Kenya and Uganda. Panel B are the border crossing points monitored by the governments of Benin and Nigeria. Panel C are the border crossing points monitored by Jibao et al. (2017), requested by the government of Sierra Leone. Panel B are the border crossing points monitored by the government of Namibia. Authors approximated the GPS coordinates by gathering information about the locations of the border crossings reported in UBOS (2006), KNBS (2012), CBN (2016), Jibao et al. (2017) and EAN (2016). Coordinates for the border crossings in Benin are obtained in Bensassi et al. (2018). 
more than 150 border crossings, with many being in remote border crossings. Panel B of Figure 5.2 shows the density of crossings which were monitored along Benin's borders. Responding to the request from the Head of the Trade Promotion Authority, Jibao et al. (2017) monitored 12 informal border crossings and seven official border crossings in Sierra Leone (Panel C of Figure 5.2). In Southern Africa, Namibia monitored informal trade at six of its border crossings from 2014 to 2016 (Panel D of Figure 5.2) (EAN 2016). Mozambique and Malawi have also implemented similar surveys (IMF 2020). In addition, there have been systematic data collection efforts by non-governmental organisations. Famine Early Warning Systems Network (FEWS NET) collect monthly data on informal cross-border trade of main staples at various border crossings across the African continent to monitor food security. Regional Agricultural Trade Intelligence Network (RATIN) also records informal cross-border trade of key agricultural goods along the borders between East African countries. While the availability of these datasets are a stepping stone to understanding ICBT, data collection efforts of governments and agencies could be shaped by various political and economic agendas, many of which are not known to researchers. As a result, researchers should be aware that depending solely on them may provide a skewed picture of the composition of goods and the extent of cross-border trade globally.

The governmental surveys have mainly been guided by the methodology documented by Ackello-Ogutu (1996). It details the methodology which the researchers followed when estimating informal trade at the borders between Kenya and Uganda, and those between Tanzania, Malawi, and Mozambique and their neighbours. This methodology consists of a two-stage process. The first stage is to obtain a list of commonly-used border crossing points, which are usually close to border towns and customs points (Ackello-Ogutu 1996). By consulting with different actors and visiting border posts, the research team eliminates border posts which do not fit a set of predefined criteria, such as prevalence of trade activities and security. In the second stage, the research team decides how frequently they will monitor the border crossing points. For example, due to resource constraints, the research team from the Ugandan government enumerates only two weeks each month. An up-rating computation can then be conducted to obtain a monthly statistic. This method of up-rating accounts for seasonality across months and days of the week. During enumeration weeks, enumerators are stationed at various points of established informal border crossings to enumerate products as traders pass by.

While this method of direct observation is cost effective, there are several factors which could lead to an underestimation of informal cross-border trade. First, direct observation places importance on the experience and attentiveness of enumerators. Enumerators could miss products travelling across borders. This is particularly the case in border crossings where the flow of goods is high and goods are varied. It is also difficult to enumerate goods which are transported in trucks and cars. Second, traders could change their behaviour when the enumerators are present. Traders might be wary of the enumerators, especially if they are known to be from the government. This could, however, be less of a concern with repeated data collection efforts as traders start to recognise that enumerators are not there to arrest them. Third, due to security concerns, enumeration only takes place during daylight. This means the quantity of goods moved at night is unknown and may be significant. Lastly, while it may be true that most informal cross-border trade activities occur in established border crossings, there still exists smuggling outside these established crossings.

One way to verify the degree of mismeasurement in these estimations is to compare data collected in the same border crossing monitored by separate governments. For example, there are overlaps in the Kenyan and Uganda data collection in the southern part of the border (Panel A in Figure 5.2). Regardless of the degree of underestimation, these surveys have shown that 
this type of informal crossborder trade is large in magnitude, in comparison with official trade recorded at the customs. For example, Bensassi et al. (2018), using the data collected by the Benin's National Institute of Statistics (INSAE), estimated that the size of informal exports from Benin to Nigeria is five times the size of formal exports. In a smaller magnitude but still substantial, BoU and UBOS estimated that informal exports from Uganda to its neighbours valued USD 538 million in 2018, which was 38\% of formal exports to its neighbours (UBOS 2019).

Having gauged the size of informal trade through these surveys, research questions on causes and consequences of informal "hidden" trade at a macro-level can be investigated. There has been a particular focus on the relationships between trade policies and smuggling. For example, Bensassi et al. (2017) observed that there are few overlaps between formal and informal trade of goods between Benin and its neighbours, and found that import bans and tariffs have a positive and significant impact on the volume of goods traded informally. Eberhard-Ruiz and Moradi (2019) and Siu (n.d.) make use of the ICBT survey dataset collected by UBOS and BoU to estimate the impact of trade policies on informal trade flows between Uganda and its neighbours. Using data collected by FEWS NET, Burke and Myers (2014) used informal trade volumes among Southern African countries in their price model and found that, in general, for trade routes with high levels of informal trade and limited government oversight, there is rapid price transmission - a way of measuring how the prices in one market affect another market. They found this result to be different when governments are heavily involved in the import of grain (Myers \& Jayne 2012), suggesting that government regulations are not impacting informal trade the same way it is impacting formal trade. Also analysing prices of staples, Porteous (2017) attributes the lack of effect of maize export bans on price differences between markets in East and Southern Africa to imperfect enforcement and the prevalence of informal trade.

\section{Quantifying behaviours}

In recent years, scholars have started to move from relying on macro-level data to collecting micro-level data on different actors involved with informal trade to understand motivations and incentives better. There have been a number of quantitative studies which make use of original surveys to document the profiles of traders. As expected, these surveys are usually conducted at border points where informal trade is known to be prevalent, for example along the border crossing points between DRC, Rwanda, Burundi and Uganda (Brenton et al. 2011, Titeca \& Celestin 2012, Croke et al. 2020), important land borders in Sierra Leone (Jibao et al. 2017, Van den Boogaard et al. 2018), main border crossing points into Botswana (Ama et al. 2013), as well as border towns between Uganda and Kenya (Tyson 2015, Siu n.d., Wiseman 2020). There are other considerations as well. Tyson (2015) made her selection based on its prevalence of smuggling, whether a relevant policy intervention has been implemented, its population density and safety concerns. While these criteria allow research to take place ethically, safely and cost effectively, these criteria can also lead to research bias where too many scholars focus on a specific location. Apart from conflict borders, there could be other border points where informal traders operate but in a less clustered manner. These traders will not be captured by surveys which focus on areas where informal trade activities are most well known.

Designing the sampling strategy is challenging in the context of smuggling. In order to ensure their sample is representative of the population, scholars pay great attention to the sampling strategy. Generally, the most practical way for a scholar to define the sampling frame is to access a list of firms/people of interest. For instance, Sequeira and Djankov (2014) and Sequeira (2016) obtained a list of all official clearing agents in Mozambique and South Africa, 
and randomly drew clearing agents to track. This, however, often is not available when surveying informal traders. Some scholars draw a random sample participants without a predefined list. For example, Titeca and Celestin (2012) conducted interviews with "every fifth trader to arrive" in all the four sites they had selected around the Great Lakes Region, and Jibao et al. (2017) chose every twentieth trader who crossed the border. This method is difficult to implement systematically on the ground, and the choice of respondents could be influenced by the enumerator's ways of working.

In the absence of a readily available list of the population to draw from randomly, some scholars seek to create their own list. Siu (n.d.) and Wiseman (2020) defined the sampling frame geographically, which involved listing traders within a predefined distance away from the official border post. Brenton et al. (2011) implemented a two-step process in their sampling strategy. They firstly listed small-scale crossborder traders who were passing through selected border crossings within a one-week period. They were informed of which markets these traders operate in. The enumeration team then went to these markets and selected the traders to survey.

Scholars collecting representative samples of informal traders have so far focused on those who trade in small volumes (e.g., Brenton et al. 2011, Titeca \& Celestin 2012 and Wiseman 2020). This particular focus could lead to research bias. For example, using their survey data, Titeca and Celestin (2012) found that small-scale informal cross-border trade in the Great Lakes region is dominated by women. While this provided an important insight, this gender ratio may not be the same when examining larger-scale informal traders.

Designing a sampling strategy such that the sample of respondents represents the population of interest is not always applicable, such as when studying networks among individuals or firms. Walther (2015) provides an approach to analyse social networks between cross-border traders. Using existing trade data, he first identifies the products important for his analysis of crossborder trade operating in the border markets located between Niger, Nigeria and Benin. He then identifies the key actors involved in trading these products. As he explains, the next steps in deciding whom to interview is fundamentally different from the sampling strategy described above.

In contrast to traditional surveys that consider social actors as independent units that can be added until they constitute a representative sample of the population, our data refer to nonindependent observations. Sampling a population would not work in our case because we don't know how the social actors are intertwined with each other before we start our analysis and, by randomly selecting some of them, we would miss a large number of relevant connections. In order to address this issue, we used snow-balling techniques. Snowball sampling is particularly adapted to the study of cross-border traders, who don't belong to a formal professional institution in which insiders could easily be distinguished from outsiders, and whose number and activities are extremely difficult to evaluate from the investigator's perspective.

This approach has been applied to different settings and questions, such as understanding the role of gender in rice trade networks (Walther et al. 2019) and livestock trade networks in West Africa (Valerio et al. 2020) Beyond deciding whom to interview, collecting quantitative data on illegal activities are challenging. It is hard to distinguish "true" information from "cheap" talk (Fisman 2009), in particular regarding bribes payment associated with informal trade. While it is impossible to know for certain, there are ways to improve the quality of the responses and to check the extent of over/under-reporting.

A starting point is to use local terms in the questionnaire, making use of the fact that "legitimacy" is not objective and fixed (Titeca \& Flynn 2014, Van den Boogaard et al. 2018). In Siu (n.d.), the questionnaire asked which border crossing s/he crossed by naming the border 
crossings, instead of imposing labels such as "informal" and "official" routes. Researchers should also be conscious about who is asking the questions and how that would affect the responses. For example, an interviewer who is also a trader working in the area might be able to gain consent from more traders to participate in the interview, but the respondents could also be dishonest when speaking to someone they know. The responses could then suffer from social desirability bias. Alternatively, traders could be suspicious of an interviewer who is not from the area, and may not agree to be interviewed.

There are also innovative methods to verify how the data collection process has altered the responses. Some traders might choose not to answer questions related to bribe payments. Bensassi and Jarreau (2019) check whether these traders have characteristics that differentiate them from other surveyed traders using econometric analysis. In Sequeira (2016), they are concerned about the reliability of the bribe data self-reported by clearing agents. To address this, they randomly selected clearing agents to be monitored by observers with experience in the shipping industry. This reduces suspicion from the clients. They found that reports of bribes are lower for clearing agents who have been monitored. However, this under-reporting is less so for cases when both the clearing agent and the client gain from the corruption activity; i.e., when tariff rates are higher.

Mixed methods also allow triangulation of information gathered using quantitative and qualitative methods. In Van den Boogaard et al. (2018), the researchers gathered information by using a quantitative survey and using qualitative methods. They highlighted that the coherence in their qualitative and quantitative data has provided them confidence that the responses which they obtained are credible.

There are other methods used in quantitative studies of other topics which could be applied in the context of smuggling. Blattman et al. (2016) proposes to verify responses to sensitive questions, such as those on crime, in quantitative surveys by randomly selecting a subset of those who were interviewed to be followed up by a qualitative researcher. The qualitative researcher then work to build a relationship with these selected respondents and elicit responses of the same questions. There are also other methods which might be more feasible if scholars are timeconstrained in their data collection period. This includes the use of list experiments where respondents are randomly provided with a list of statements: one set has a sensitive statement and the other does not (McKenzie \& Siegel 2013). They then verify survey responses using administrative data (Deming 2011).

Quantitative surveys are not only a tool to collect information about the characteristics of traders and other actors, but also are used to answer questions, such as, "What changes the behaviour of actors?" and "How do the behaviours of actors change over time?". One method to answer these questions is for scholars to design and evaluate a programme which may affect traders' behaviour over time. Croke et al. (2020) test whether a training programme targeted at small-scale informal cross-border traders reduces bribery payments by using a randomised control trial (RCT). Within their sample of 628 cross-border traders, they randomly selected half to participate in a training workshop. With this method, they were able to compare the outcomes of those who participated in the workshop and those who did not. While this methodology is common in quantitative studies, applying it to smuggling-related research can be particularly challenging. One challenge is to trace the participants, as the authors admit that some traders provided false names at baseline. Two years after their baseline, out of their original sample of 628 cross-border traders, they were only able to track $84 \%$ of the sample.

Other studies examine changes in the behaviour of actors by combining both macro and micro-level data. Sequeira (2016) examines what happens to tariff evasion (measured by the trade gap) and the amount of bribes paid (measured using firm-level data) as a result of a policy 
aiming at reducing tariffs for certain imports into Mozambique. Some products have changed tariffs, while others have not. This variation allows the author to compare outcomes of these two groups. Similarly, Siu (n.d.) first uses macro-level formal and informal trade flow data to understand whether a border facility has reduced informality, and then she gathers trade-level data to understand who chooses to cross the border informally. Chalendard et al. (2020) uses both administrative and survey data to examine how customs officers' behaviour changed as a result of being provided third-party information on import values. After using administrative data to understand changes in inspection actions change, as described in Section 3, they investigate whether better information provided by the in-house team improved customs performance using a RCT. By using both methods, they are able to understand how information affects customs performance in a more nuanced manner.

\section{Future research agenda}

This chapter provides a dissection of the general term "smuggling" for quantitative analysis. Equation 5.2 describes the value of total bilateral trade for a specific product.

$$
\text { Total } \text { Trade }=\text { Reported Trade }+ \text { Missing Trade }+ \text { Hidden Trade }
$$

For too long, Missing Trade has been ignored and Hidden Trade has been considered negligible. The assumptions on which this relies are wrong. By using creative methods, scholars have revealed that missing trade can be important even for trade between developed countries (Stoyanov 2012). Recently, with governments and international organisations shifting their perspectives away from thinking about informal trade as a purely criminal activity, scholars have made inroads into quantifying "hidden" trade. As captured by previous qualitative studies, this type of smuggling is found to be a fundamental component of trade among developing nations (Bensassi et al. 2018). These studies show that the size and characteristics of hidden trade vary across country pairs on the basis of trade barriers, currency movements and the state capacity of the countries concerned.

True, missing trade and hidden trade are inherently difficult to measure. As we have seen in the past, however, this endeavour is worth pursuing. Working with a largely theoretical economics literature on smuggling, Bhagwati (1964) took up the huge empirical challenge of quantifying smuggling with basic trade statistics readily available. His method of mirror statistics has paved the way for the next generation of scholars. By applying Bhagwati's (1964) method into econometric analysis, scholars have made great strides in quantifying the extent to which trade and tax policies, as well as institutional factors such as corruption, affect smuggling. Efforts in collecting data on hidden trade have provided governments with a more accurate view of their country's trade balance. Scholars collecting micro-data on different actors have provided important insights into the mechanisms behind smuggling and the incentives of different actors. Scholars have also begun to quantify the extent to which behaviours adapt when faced with operational and environmental changes.

Despite recent headway, quantitative studies on smuggling remain relatively thin, with many questions still unanswered and challenges left untackled. First, precision in detecting missing trade can be improved by designing new quantitative methods beyond the use of mirror statistics. There are fresh opportunities to use transactional data at the customs level, as more customs offices work towards digitalising and automating their operations. Some governments have even been working towards linking previously siloed administrative datasets, such as transactions data at customs and income taxpayer data, for research purposes. To improve 
knowledge about hidden trade, we call on governments of nations where there is a high prevalence of informal trade (revealed through qualitative evidence) to follow the example of Uganda and systematically estimate informal trade at land borders. By publishing these estimates, scholars can then make use of these resources to generate better knowledge of the interdependence between informal and formal trade, and to quantify the extent to which these activities can contribute to or hinder economic development goals.

At a micro-level, more attention is needed to understand how survey respondents answer questions related to smuggling. Scholars can adopt methods designed for other research areas, as we have highlighted in this Chapter. More pertinently, scholars should complement qualitative approaches with quantitative methods. Triangulation of different data sources, across disciplines, will not only reduce the likelihood of inaccurate conclusions based on biased data, but will also provide a more holistic picture of the research question at hand. This direction could overcome some of the existing challenges in understanding actors involved in smuggling activities over time, the true incentives behind their decision-making, and their real responses when faced with new barriers and opportunities.

Future studies should venture beyond the current focus of existing quantitative studies. We should acknowledge that scholars have only begun the journey of estimating "hidden" trade. We still know little about the prominence and size of trade activities in remote areas, far away from key border towns where most studies have been situated. Night trade activities, due to safety concerns, are also less quantified. With the focus on smuggling of legal goods, methods to quantify smuggling of illicit goods remain elusive. Yet with the help of technology and new ways of data collection, such as collection of user data by the mobile phone app Sauti (which is targeted towards supporting cross-border traders), some of these barriers could be overcome in the future. There should be a shift away from focusing on small-scale traders to understand how and why traders of different sizes enter, thrive, survive, and exit the profession. There should also be a better spread of studies in different countries and continents, from countries in Africa, where most research on informal cross-border trade takes place, to Asia and South America. A more diverse body of studies will enable researchers to verify the extent to which these methods are applicable in different contexts. By further refining and expanding the toolbox of methods to quantifying smuggling, we then can understand better the extent to which informal trade is operated and incentivised differently across cultures, climates and institutions. A collective effort to reduce research bias will be a promising way forward to produce richer and more relevant research which would not provide benefits only to a selected convenient few.

\section{Notes}

1 Azam (2007) and Golub (2015) provide a good summary.

2 Notice that this formulation has to be modified to take into account of the case where only one of country has reported a trade flow and is similar to calculation of the trade gap as a share of the import value of the good: gapvalue $=($ Export - Import $) /$ Import .

3 For example, the leading digit of 187 is 1.

\section{References}

Ackello-Ogutu, C. (1996), Methodologies for estimating informal crossborder trade in Eastern and Southern Africa: Kenya/Uganda border, Tanzania and its neighbors, Malawi and its neighbors Mozambique and its neighbors, Technical Paper No. 29. http://hdl.handle.net/11295/49521. 
Afrika, J.-G. K. \& Ajumbo, G. (2012), Informal cross border trade in Africa: Implications and policy recommendations, Africa Economic Brief, AfDB, Abidjan: African Development Bank. https://www. afdb.org/fileadmin/uploads/afdb/Documents/Publications/Economic\%20Brief\%20-\%20Informal $\% 20$ Cross $\% 20$ B order $\% 20$ Trade $\% 20$ in $\% 20$ Africa $\% 20$ Implications $\% 20$ and $\% 20$ Policy \%20Recommendations\%20-\%20Volume\%203.pdf.

Ama, N. O., Mangadi, K. T., Okurut, F. N. \& Ama, H. A. (2013), 'Profitability of the informal crossborder trade: A case study of four selected borders of Botswana', African Journal of Business Management 7(40), 4221-4232.

Azam, J.-P. (2007), The welfare implications of unrecorded cross-border trade, in J.-P. Azam, ed., Trade, Exchange Rate, and Growth in Sub-Saharan Africa, Cambridge University Press, Cambridge, chapter 2.

Bensassi, S., Brockmeyer, A., Pellerin, M. \& Raballand, G. (2017), 'Algeria-Mali trade: The normality of informality', Middle East Development Journal 9(2), 161-183.

Bensassi, S. \& Jarreau, J. (2019), 'Price discrimination in bribe payments: Evidence from informal crossborder trade in West Africa', World Development 122, 462 - 480. URL: http://www.sciencedirect.com/science/ article/pii/S0305750X19301433.

Bensassi, S., Jarreau, J. \& Mitaritonna, C. (2018), 'Regional Integration and Informal Trade in Africa: Evidence from Benin's Borders', Journal of African Economies 28(1), 89-118. https://doi.org/10.1093/ jae/ejy016.

Berger, H. \& Nitsch, V. (2008), Gotcha! A Profile of Smuggling in International Trade, Working Paper Series, Munich, Germany: CESifo.

Bhagwati, J. (1964), 'On the underinvoicing of imports', Oxford Bulletin of Economics and Statistics 27(4), 389-397.

Bhagwati, J. (1967), Fiscal Policies, the Faking of Foreign Trade Declarations, and the Balance of Payments, Bulletin of the Oxford University Institute of Economics \& Statistics 29(1), 61-77. https:// doi.org/10.1111/j.1468-0084.1967.mp29001004.x.

Bhagwati, J. \& Hansen, B. (1973), 'A theoretical analysis of smuggling', The Quarterly Journal of Economics $87(2), 172-187$.

Blattman, C., Jamison, J., Koroknay-Palicz, T., Rodrigues, K. \& Sheridan, M. (2016), 'Measuring the measurement error: A method to qualitatively validate survey data', Journal of Development Economics 120, 99-112.

Bouet, A. \& Roy, D. (2012), 'Trade protection and tax evasion: Evidence from Kenya, Mauritius, and Nigeria', The Journal of International Trade and Economic Development 21(2), 287-320.

Brenton, P., Bucekuderhwa, B., Hossein, C., Nagaki, S. \& Ntagoma, J. (2011), 'Risky business: Poor women cross-border traders in the great lakes region of Africa', Technical Report 11, Washington, DC: World Bank.

Burke, W. J. \& Myers, R. J. (2014), 'Spatial equilibrium and price transmission between southern African maize markets connected by informal trade', Food Policy 49, 59-70.

CBN (2016), Measuring informal cross-border trade in Nigeria, Report, Abuja: Central Bank of Nigeria.

Chalendard, C. R., Duhaut, A., Fernandes, A. M., Mattoo, A., Raballand, G. J. \& Rijkers, B. (2020), 'Does better information curb customs fraud?', World Bank Policy Research Working Paper No. 8371. https://ssrn.com/abstract $=3633656$.

Croke, K., Garcia Mora, M. E. Goldstein, M., Mensah, E. \& O'Sullivan, M. (2020), 'Up before dawn: Experimental evidence from a cross-border trader training at the Democratic Republic of Congo-Rwanda Border', World Bank Policy Research Working Paper No. 9123. https://ssrn.com/ abstract $=3526525$.

de Boyrie, M. E., Pak, S. J. \& Zdanowicz, J. S. (2005a), 'Estimating the magnitude of capital flight due to abnormal pricing in international trade: The Russia-USA case', Accounting Forum 29(3), 249 - 270. Tax avoidance and global development. http://www.sciencedirect.com/science/article/pii/S0155998205 000268 .

de Boyrie, M., Nelson, J. \& Pak, S. (2007), 'Capital movement through trade misinvoicing: The case of Africa', Journal of Financial Crime 14, 474-489.

de Boyrie, M., Pak, S. \& Zdanowicz, J. (2005b), 'The impact of Switzerland's money laundering lawon capital flows through abnormal pricing in international trade', Applied Financial Economics 15(4), 217-230. https://EconPapers.repec.org/RePEc:taf:apfiec:v:15:y:2005:i:4:p:217-230.

Deardorff, A. V. \& Stolper, W. E. (1990), 'Effects of smuggling under African conditions: A factual, institutional and analytic discussion', Weltwirtschaftliches Archiv 126(1), 116-141.

Deming, D. J. (2011), 'Better schools, less crime?’, The Quarterly Journal of Economics 126(4), 2063-2115. 
Demir, B. \& Javorcik, B. (2020), 'Trade policy changes, tax evasion and Benford's law', Journal of Development Economics 144, 102456. http://www.sciencedirect.com/science/article/pii/S030438782 030031619.

Dercon, S. \& Ayalew, L. (1995), 'Smuggling and supply response: Coffee in Ethiopia', World Development 23(10), 1795-1813.

Dutt, P. \& Traca, D. (2010), 'Corruption and bilateral trade flows: Extortion or evasion?', The Review of Economics and Statistics 92(4), 843-860.

EAN (2016), Informal cross-border trade report, Report, Namibia: Economic Association of Namibia.

Eberhard-Ruiz, A. \& Moradi, A. (2019), 'Regional market integration in East Africa: Local but no regional effects?', Journal of Development Economics 140, 255-268.

Ferrantino, M. J., Liu, X. \& Wang, Z. (2012), 'Evasion behaviors of exporters and importers: Evidence from the U.S.-China trade data discrepancy', Journal of International Economics 86(1), 141-157. http:// www.sciencedirect.com/science/article/pii/S0022199611000924

Fisman, R. (2009), 'Measuring tariff evasion and smuggling', NBER Reporter Online (3), 8-10.

Fisman, R. \& Wei, S.-J. (2004), 'Tax rates and tax evasion: Evidence from “missing imports” in China', Journal of Political Economy 112(2), 471-496.

Forstater, M. (2018), 'Illicit financial flows, trade misinvoicing, and multinational tax avoidance: the same or different?', CGD policy paper 123, 29.

Golub, S. (2015), Informal cross-border trade and smuggling in Africa, in O. Morrissey, K. Sharma \& R. A. López, eds, Handbook on Trade and Development, Edward Elgar Publishing, chapter 10.

Golub, S. S. \& Mbaye, A. A. (2009), 'National trade policies and smuggling in Africa: The case of the Gambia and Senegal', World Development 37(3), 595 - 606. http://www.sciencedirect.com/science/ article/pii/S0305750X08002234.

Igue, J. O. \& Soule, B. (1992), L'Etat Entrepôt au Bénin: Commerce Informel ou Réponse a la Crise?, Khartala: Paris.

IMF (2020), Nigeria: Informal trade with neighboring countries, Technical report, IMF. https://www.imf.org/ en/Data/Statistics/informal-economy-data/Reports/nigeria-informal-trade-with-neighboring-countries.

INSAE (2011), Enquête sur le commerce non enregistré au cordon douanier, Rapport, Institut National de la Statistique et de l'Analyse Economique, Cotonou.

Javorcik, B. \& Narciso, G. (2008), 'Differentiated products and evasion of import tariffs', Journal of International Economics 76(2), 208-222. https://EconPapers.repec.org/RePEc:eee:inecon:v:76:y:2 008:i:2:p:208-22220.

Javorcik, B. S. \& Narciso, G. (2017), 'WTO accession and tariff evasion', Journal of Development Economics 125, 59-71. http://www.sciencedirect.com/science/article/pii/S0304387816300840.

Jean, S. \& Mitaritonna, C. (2010), 'Determinants and pervasiveness of the evasion of custom duties', CEPII, WP N 2010-26. https://doi.org/10.22004/ag.econ.115432.

Jibao, S., Mahoi, I. \& Sandy, J. F. (2017), The realities of cross-border trade from Sierra Leone to other Mano River countries, Report, International Growth Center. https://www.theigc.org/publication/ realities-cross-border-trade-sierra-leone-neighbours/.

Kellenberg, D. \& Levinson, A. (2019), 'Misreporting trade: Tariff evasion, corruption, and auditing standards', Review of International Economics 27(1), 106-129. URL: https://onlinelibrary.wiley.com/ doi/abs/10.1111/roie.12363.

KNBS (2012), Informal cross border trade 2012, Documentation, Kenya: Kenya National Bureau of Statistics.

Koroma, S., Nimarkoh, J., You, N., Ogalo, V. \& Owino, B. (2017), Formalization of informal trade in Africa: Trends, experiences and socio-economic impacts, Report, Food Agric. Organ. Accra. http:// www.fao.org/3/a-i7101e.pdf.

Levin, J. \& Widell, L. M. (2014), 'Tax evasion in Kenya and Tanzania: Evidence from missing imports', Economic Modelling 39, 151-162.

Martin, L. \& Panagariya, A. (1984), 'Smuggling, trade, and price disparity: A crime-theoretic approach', Journal of International Economics 17(3-4), 201-217.

McKenzie, D. \& Siegel, M. (2013), 'Eliciting illegal migration rates through list randomization', Migration Studies 1(3), 276-291.

Mengistu, A. T., Molla, K. G. \& Mascagni, G. (2018), 'Tax evasion and missing imports: Evidence using transaction level data in Ethiopia', ICTD Working Paper 101.

Mishra, P., Subramanian, A. \& Topalova, P. (2008), 'Tariffs, enforcement, and customs evasion: Evidence from India', Journal of Public Economics 92(10), 1907-1925. 
Myers, R. J. \& Jayne, T. (2012), 'Multiple-regime spatial price transmission with an application to maize markets in Southern Africa', American Journal of Agricultural Economics 94(1), 174-188.

NISR (2014), Informal cross border trade statistics in Rwanda, Presentation made in Addis Ababa.

Paul, K., Pak, S., Zdanowicz, J. \& Curwen, P. (1994), 'The ethics of international trade: Use of deviation from average world price to indicate possible wrongdoing', Business Ethics Quarterly 4(1), 29-41. http://www.jstor.org/stable/385755721.

Pitt, M. M. (1981), 'Smuggling and price disparity', Journal of International Economics 11(4), 447-458. https://ideas.repec.org/a/eee/inecon/v11y1981i4p447-458.html.

Porteous, O. (2017), 'Empirical effects of short-term export bans: The case of African maize', Food Policy 71, 17-26.

Rijkers, B., Baghdadi, L. \& Raballand, G. (2017), 'Political connections and tariff evasion evidence from Tunisia', The World Bank Economic Review 31(2), 459-482.

Sequeira, S. (2016), 'Corruption, trade costs, and gains from tariff liberalization: Evidence from Southern Africa', American Economic Review 106(10).

Sequeira, S. \& Djankov, S. (2014), 'Corruption and firm behavior: Evidence from African ports', Journal of International Economics 94(2), 277-294.

Sheikh, M. A. (1974), 'Underinvoicing of imports in Pakistan', Oxford Bulletin of Economics and Statistics 36(4), 287-296.

Siu, J. (n.d.), Formalising informal cross-border trade: Evidence from One-Stop-Border-Posts in Uganda, Technical Report. Retrieved from https://papers.ssrn.com/sol3/papers.cfm?abstract_id=3854156.

Stoyanov, A. (2012), 'Tariff evasion and rules of origin violations under the Canada-U.S. Free Trade Agreement', Canadian Journal of Economics/Revue canadienne d'économique 45(3), 879-902. URL: https://onlinelibrary.wiley.com/doi/abs/10.1111/j.1540-5982.2012.01719.x.

Thursby, M., Jensen, R. \& Thursby, J. (1991), 'Smuggling, camouflaging, and market structure', The Quarterly Journal of Economics 106(3), 789-814.

Titeca, K. \& Celestin, K. (2012), Walking in the Dark: Informal Cross-Border Trade in the Great Lakes Region, Technical report, International Alert.http://hdl.handle.net/1854/LU-4161492.

Titeca, K. \& Flynn, R. (2014), “Hybrid governance” legitimacy, and (il) legality in the informal crossborder trade in Panyimur, northwest Uganda', African Studies Review 57(1), 71-91.

Tyson, J. (2015), 'Effect of sub-Saharan African trade corridors on vulnerable groups', ODI Report. London: ODI.

UBOS (2006), The informal cross border trade survey report, Technical report, Kampala: Ugandan Bureau of Statistics.

UBOS (2019), The informal cross border trade survey report, Technical report, Kampala: Ugandan Bureau of Statistics. 22.

Valerio, V. C., Walther, O. J., Eilittä, M., Cissé, B., Muneepeerakul, R. \& Kiker, G.A. (2020), 'Network analysis of regional livestock trade in West Africa', PloS one 15(5), e0232681.

Van den Boogaard, V., Prichard, W. \& Jibao, S. (2018), 'Norms, networks, power and control: Understanding informal payments and brokerage in cross-border trade in Sierra Leone', Journal of Borderlands Studies 33 pp. 1-21.

Vézina, P.-L. (2015), 'Illegal trade in natural resources: Evidence from missing exports', International Economics 142, 152-160. Economics of Global Interactions. http://www.sciencedirect.com/science/ article/pii/S2110701714000481.

Walther, O. J. (2015), 'Business, brokers and borders: The structure of West African trade networks', The Journal of Development Studies 51(5), 603-620.

Walther, O. J., Tenikue, M. \& Trémolières, M. (2019), 'Economic performance, gender and social networks in West African food systems', World Development 124, 104650.

WCO (2018), Illicit financial flows via trade mis-invoicing, Technical report, Brussels: World Custom Organisation.

Wiseman, E. (2020), Trade, informality and corruption: Evidence from small-scale traders in Kenya during Covid-19, Working paper.

Worku, T., Mendoza, J. P. \& Wielhouwer, J. L. (2016), 'Tariff evasion in sub-Saharan Africa: The influence of corruption in importing and exporting countries', International Tax and Public Finance 23(4), 741-761.

Yang, D. (2008), 'Can enforcement backfire? Crime displacement in the context of customs reform in the Philippines', The Review of Economics and Statistics 90(1), 1-14. 